\title{
The Impacts of Independent Director and CEO Duality on Performance in the Chinese Post-Institutional-Transition Era
}

\author{
Yong Kyu Lew (Corresponding author) \\ College of Business Administration, Hankuk University of Foreign Studies \\ Seoul, Republic of Korea
}

Jing Yu

China Development Bank

Jinan, Shandong Province, People's Republic of China

\section{Jeong-Yang Park}

Nottingham University Business School, The University of Nottingham

Nottingham, United Kingdom

This is a pre-print (non-publisher's document). Please cite this article as below:

Lew, Y. K., Yu., J., and Park, J-Y. (2017). The Impacts of Independent Director and CEO Duality on Performance in the Chinese Post-Institutional-Transition Era, Canadian Journal of Administrative Sciences. (accepted and forthcoming) 


\begin{abstract}
This paper investigates the influence of corporate governance on performance of modern Chinese firms. Prior studies reveal inconclusive results about the relationship between corporate governance and firm performance. Little research investigates the performance implications of board structure in the post-institutional-transition era in China. Based on agency and resource dependence theories, it examines the impacts of board composition and leadership structure on the performance of Chinese manufacturing firms that went public on the Shanghai and Shenzhen Stock Exchanges in 2010. The findings show that separating the posts of CEO and chairman promotes better performance. However, appointing a larger proportion of outside independent directors to the board insignificantly affects performance. This research provides partial support for agency theory and extended insights into corporate governance in emerging economy firms.
\end{abstract}

Keywords: agency theory, board independence, CEO duality, China, corporate governance, institutional transition. 


\section{Introduction}

The recent financial crisis and high-profile corporate scandals at Enron, Lehman Brothers, WorldCom, and other companies have led stakeholders to take an interest in the construction of an effective corporate governance (CG) system (Ehikioya, 2009; Erkens, Hung and Matos, 2012). A well-functioning CG system leads to the success of the ideal type of firm and strategies (Whitley, 2007). Thus it allows the firm to build a foundation for performance and shelters it from environmental vulnerability. For emerging economy firms, market supporting institutions and a well-functioning CG system enable them to attract foreign investment and gain advanced knowledge from multinational corporations (MNCs) through partnerships (Filatotchev et al., 2007; Meyer, 2004). Although the emerging economies have benefited from foreign investment in recent years, local firms in these economies are often discounted in the international capital market due to their underdeveloped and opaque CG systems (UNCTAD, 2015). This highlights the importance of CG system for emerging economy firms, since the establishment of an effective CG system will help them to attain higher market valuations and positions in the international capital market. The CG literature notes that various forms of CG exist to ensure that the management endeavors to meet the best interests of the shareholders. These include external CG mechanisms (e.g., the market for corporate control, institutional ownership and the level of debt financing) and internal ones (e.g., the board of directors, managerial ownership and executive compensation) (Barnhart and Rosenstein, 1998; Monks and Minow, 2004).

The board of directors (BOD) plays a particularly important part in the establishment of effective CG (Daily and Dalton, 1994; Krause, Semadeni and Cannella, 2013; Xie, Davidson and DaDalt, 2003) as it directs the firm's strategy at the apex of corporate level (Baysinger and Hoskisson, 1990; Walker and Madsen, 2014). Conventional wisdom states 
that a more independent board will be more effective and thus it improves firm performance. However, the extant literature provides rather mixed results on this (see, e.g., Agrawal and Knoeber, 1996; Bhagat and Black, 2000; Hermalin and Weisbach, 1991; Kiel and Nicholson, 2003; Xie et al., 2003). Regarding this topic, a majority of prior studies have focused on BODs and their performance implications in developed economies. However, each country has a different institutional setting, formed by various aspects such as the economic environment, government regulations, and level of development of the financial markets (Berry, Guillén, and Zhou, 2010; Khanna and Palepu, 2004; Li, Cui, and Lu, 2014). In comparison with the CG of developed economy firms, different institutional settings known as the rules of the game, such as more concentrated ownership and weaker legal constraints, will affect the CG practices of emerging economy firms (Klapper and Love, 2004; Wright et al., 2005).

This research examines the extent to which independent corporate board structure affects the performance of Chinese firms that have gone public since China's institutional transitions (cf. Peng, 2004; Peng, Zhang, and Li, 2007). This approach is relevant in the emerging economy context and fills some gaps in the emerging market CG literature.

There has been an ongoing controversy regarding the influence of the BOD on firm performance between two theoretical approaches, i.e., agency theory (Fama, 1980; Jenson and Meckling, 1976) and stewardship theory (Davis, Schoorman and Donaldson, 1997; Peng et al., 2007). Although the debate remains unresolved in the literature, two practices, namely, (1) appointing outside directors to the board and (2) separating the posts of CEO and chairman (CEO non-duality), have been advocated by governments of emerging economies experiencing institutional transitions, including China (Peng, 2004). The 'China Securities 
Regulatory Commission' (CSRC) ${ }^{1}$, the regulatory government body, has been developing and improving institutional framework for the CG of listed companies in China and joined the international standard-setting 'International Organization of Securities Commissions (IOSCO)' Technical Committee in $2009^{2}$ (OECD, 2011; 2015). This marks that China has moved to the post-institutional-transition passing through transitions eras from 1980s to early 2000s regarding CG. Nevertheless, whether these practices mandated through statutory regulations really pay off in terms of improved financial performance still remains unknown. As such, this study develops and tests hypotheses regarding the influences of BOD composition and leadership structure on firm performance in the modern Chinese context. The application of the relationship based on agency theory fits the current research as Chinese state-owned-enterprise (SOE) reforms and CG guideline changes have been taking place in China (Aivazian, Ge and Qiu, 2005; Hassard et al., 2006; Peng et al., 2007; Tian and Lau, 2001). As such, this research integrates CG research with agency and resource dependence theories to develop and test a comprehensive explanation of the implications of board structure in the post-institutional-transition era in the emerging economy of China. It investigates aspects of independent corporate board structure and performance and to this end, it aims to answer the following research question: Do board independence and CEO duality affect financial performance in China, and if so to what extent?

The contribution of this research to the CG literature is two-folds. First, previous

\footnotetext{
1 The 'Code of Corporate Governance for Listed Companies' is regulated by the CSRC in China (see http://www.csrc.gov.cn).

${ }^{2}$ We acknowledge institutions are in a state of flux in emerging economies and even developed economies (see Brexit). China's financial markets have continued to experience transitions. However, from the CG perspective we view that joining to the IOSCO technical committee requires China to significantly change the CG-related legal framework. This can be seen as the critical evidence that the unstable institutions become stabilized and improved, comparing with the unstable institutional transition periods from 1980s to early 2000s (see e.g., Berglöf and von Thadden, 2000; Hassard et al., 2006; Lin and Germain, 2003; Tanner, 1999; McCann, 2014; OECD; 2011; Reuter, 2015).
} 
studies on Chinese CG are limited and their empirical results are rather mixed (Bai et al., 2004; Bozec and Bozec, 2012; Peng et al., 2007; Tian and Lau, 2001). By focusing on the CG practices of emerging economy firms, this research extends the literature on the impact of board independence on firm performance during China's institutional transition period (cf. Peng, 2004; Peng et al., 2007) to that in the post-regulation period. Second, it investigates whether the prevalent institutional regulatory change towards more outsiders on boards leads to better financial performance in the modern Chinese context. Thus, it offers a nuanced implication that management needs to formulate strategies for the establishment of wellfunctioning CG structures that can contribute to improving firm performance. In so doing, it provides deeper insights for various stakeholders, including foreign and domestic investors, shareholder activists, managers, and public policy makers.

\section{Research context}

The research context of this paper is newly initial public offering (IPO) firms in 2010 on either the Shanghai or the Shenzhen Stock Exchange in China. The Shanghai Stock Exchange had a total of 894 firms and the Shenzhen Stock Exchange had a total of 1,169 listed firms in 2010. From these listed firms, we focused on 102 newly listed firms on the Shanghai and the Shenzhen Stock Exchange in 2010 in the manufacturing sector.

There are two important reasons for the selection of the research context. First, the research sets to illustrate the changing institutional environment and the impact of new regulations in particular, the introduction of new regulations following China joining IOSCO in 2009. In addition, the CSRC significantly improved securities legal framework and market transparency by 2009. For example, the CSRC (2011) disseminated the guidelines and 
promulgated several important regulatory documents ${ }^{3}$, including Compilation Rules for Information Disclosure by Companies Offering Securities to the Public No.15 and Compilation Rules for Information Disclosure by Companies Offering Securities to the Public No. 9.

Second, when transitioning to an IPO stage although all publicly listed firms may associate with the 'common law' of CG, varying industries will differ in important ways that lead to expect differences in formal regulatory setting of the IPO firms' characteristics. There are other institutional factors at play that may influence regulatory environment. This study focuses exclusively on newly listed manufacturing firms in China which operate within a similar regulatory environment. This was due to many of Chinese manufacturing SOEs experienced the SOE reforms (McCann, 2014; Motohashi and Yun, 2007; Wang et al., 2009) which set the performance impacts of the SOE restructuring measures on CG more observable.

The post-institutional-transition period after 2009 is thus chosen for this research setting. Moreover, the year 2010 is chosen as the base year in this research for the following reasons. Thus we collected data from 2010 onward is relatively well updated and the information disclosure requirement imposed on publicly listed firms is stricter than before that date (CSRC, 2011). Furthermore, the number of IPOs in 2010 was much greater than in previous years (CSRC, 2011), making the research sample large enough for our research purposes. The required information on board composition and board leadership structure was obtained from the sample firms' prospectuses for share offering and IPO statements. Thereby, the focus of newly listed firms in the manufacturing sector in 2010 provides a useful research context for the study of the CG-performance relationship in the post-institutional-transition.

\footnotetext{
3 The CSRC (2011) issued and disseminated three types of regulations and 40 normative documents in 2010.
} 


\section{Theory and Hypothesis Development}

\section{Theoretical background}

There are various forms of CG, safeguarding the firm to meet the shareholders' interests. Such forms include external ones including the market for corporate control, institutional ownership, and the level of debt financing, and internal ones such as the board subcommittees, managerial ownership, and executive compensation (Monks and Minow, 2004). As discussed earlier, this research is particularly interested in internal CG (i.e., board independence) and its financial performance implications. The BOD is defined as a body of appointed executive individuals who jointly direct and oversee a firm, thus directing the firm's strategy and performance (Baysinger and Hoskisson, 1990; Luoma and Goodstein, 1999; Monks and Minow, 2004). The BOD has three main functions: strategic, control, and resource dependence. First, it is responsible for setting a vision and corporate goals, and formulating, implementing, and evaluating strategies. It also has the ability to bring external resources to the firm, including both human and financial resources. Second, it has the power to select, dismiss, and compensate senior management team based on performance appraisals. Lastly, it embeds in social networks and communicates itself with external actors in the environment (Withers, Hillman and Cannella, 2012). The BOD plays these important roles in the firm, and is expected to resolve conflicts of interests between the various stakeholders, including the shareholders. Thus, the structuring of BOD is of crucial importance. This section reviews two theories adopted in this research, i.e., the agency and resource dependence theories.

Agency theory has been widely used in CG research (Fama, 1980; Jenson and Meckling, 1976). Its first assumption is that information asymmetry between shareholders (as principals) and managers (as agents) in the free market economy results in ineffective agency, 
high agency costs, and losses to the shareholders. Both principals and agents are viewed as rational individuals who are self-seeking and opportunistic - the agents are concerned with their own salaries, status, and security rather than the shareholders' returns. Thus, there is an inherent conflict between the benefits to the shareholders and to the managers (Tian and Lau, 2001). Under these circumstances, motivating managers to maximise shareholders' returns instead of acting in their own interests is the fundamental role of the BOD (Fama, 1980). Effective monitoring and control systems should also be established to discipline managers and protect shareholders' interests. In this vein, agency theory advises having a substantial number of independent external directors on the board and the separation of the posts of CEO and chairman (i.e., CEO non-duality) (OECD, 1999; 2015). Specifically in China, statutory regulations and government CSRC guidelines in recent years reveal a near consensus in favor of strengthening board independence (see OECD, 2011).

Some scholars focus on the social networks in which firms are embedded (Scott, 1991), and thus the significance of these interlocking directorates for power within society. Such research provides the foundation of the resource dependence theory, which argues that the board is an important tie between the firm and the resources in the external environment (Hillman, Cannella and Paetzold, 2000; Kiel and Nicholson, 2003). The more resourceabundant outside directors are appointed to the board to help bring external resources into the firm, the better the organisational outcomes are (Peng, 2004). As such, bringing in outsiders with social-network links to strategically associated enterprises facilitates companies' strategic decision-making process (Withers et al., 2012). The resource dependence role of the board is more pronounced in specific institutional contexts, such as that in China: 'Both the Chinese cultural propensity to rely on relationships (guanxi) to get things done and the institutional imperative to activate social network ties during institutional transitions are claimed to be behind the highlighted role of resource dependence' (Peng, 2004, p.455). 
Although resource dependence theory underemphasises the alternative functions of the board, such as strategizing, counseling, and monitoring (Kiel and Nicholson, 2003), it complements agency theory as it explains how resource- and information-constrained internal boards can take advantage of external expertise.

In all, it would be challenging to explain the relationship between board independence and firm performance based on a single theory (Bozec and Bozec, 2012). 'The combination of these two theoretical perspectives is consistent with the earlier work [...] that asserts boards of directors serve two important functions: monitoring management on behalf of shareholders (agency theory) and bringing in essential resources (resource dependency theory)' (Jackling and Johl, 2009, p.494). As shown in Figure 1, drawing on agency and resource dependence theories the following section develops hypotheses regarding the relationships between board composition and leadership structure and financial performance ${ }^{4}$.

\section{Insert Figure 1 here}

\section{Independent board composition}

In developed economies, it is generally recommended that publicly traded firms in the stock market should appoint a sufficient number of independent external directors to mitigate CG risks and failures, based on the Cadbury Report of $1992^{5}$ (ICAEW - The Institute of Chartered Accountants in England and Wales, 2015; Hussainey and Al-Najjar, 2012). This recommendation has been widely adopted to varying degrees by the World Bank, the EU, the

\footnotetext{
${ }^{4}$ There are different approaches to analyzing board independence, looking at elements such as board subcommittees (e.g., the audit committee, remuneration committee, and nomination committee that perform specific board duties) and director ownership (e.g., the view that director ownership motivates directors to take the dayto-day business seriously and to act in the best interests of the firm). The focus of the current research is board composition (board independence) and leadership structure (CEO non-duality).

${ }^{5}$ In advanced economies such as the UK, the US, Germany, and Japan, governments set up codes of CG for firms. Examples include the Cadbury, Hampel and Turnbell Reports in the UK, the Business Roundtable in the US, the German Code of Corporate Governance, and the Corporate Governance Principles in Japan. These codes of conduct largely advocate board independence based on agency theory.
} 
US, and many other countries, including China (Peng, 2004). Although board independence has been widely proposed in government CG guidelines as an effective approach for improving firm performance, extant studies provide rather mixed empirical results on the relationship between board composition and firm performance.

Drawing on agency theory, it is argued that firms are continually confronted with agency problems (Eisenhardt, 1989; Fama and Jensen, 1983; Tian and Lau, 2001). Managers are likely to sacrifice shareholders' interests for their own benefit when conflicts arise. Hence, a BOD with the statutory right to employ, dismiss, and compensate managers will promote shareholders' wealth and mitigate CG risks (Williamson, 1984). The BOD should be objective and independent in order to achieve the monitoring goal. As such, it should comprise a minimum number of independent directors (Tian and Lau, 2001; Weir and Laing, 2001). Independent directors can serve their roles as a member of the BOD more effectively than inside and affiliated directors because they have no material relationship with the firm. In contrast, inside and affiliated directors are likely to be manipulated by the self-serving managers and collude with them to maximise their personal interests at the expense of the firm. However, the previous studies on board independence and financial performance provide inconclusive results, including positive (Peng, 2004; Rosenstein and Wyatt, 1997), negative (Hossain, Cahan and Adams, 2000; Kiel and Nicholson, 2003) and no relationship (Hermalin and Weisbach, 1991). Thus, it seems that this association is influenced by the research context (Peng et al., 2007).

Institutional pressures such as government-driven formal regulations can impact on board composition and subsequent changes in firm performance. For instance, Dahya and McConnell (2007) analyze the impact of board composition changes on financial performance in the UK over the period of 1989 through 1996, during which time the Cadbury Report was published. Their results indicate that firms that appointed more independent 
directors to conform to the standard experienced a significant increase in operating profits and stock prices. Also, the Principle of Corporate Governance (OECD, 1999) emphasises that a board should include a sufficient number of independent directors, who can express independent opinions, monitor managers' behaviours, and settle conflicts of interests between principals and agents. In a similar vein, since 2003, the committee of the CSRC has urged publicly listed firms in China to make at least one-third of the five to nineteen members of the board they must appoint independent directors (CSRC, 2003). In the Chinese context, boards consist of three different types of director: inside, affiliated, and independent. Inside directors, who are quite familiar with the firm, have direct responsibility for managing daily operations. Affiliated directors represent the 'sponsor enterprise' (SOEs before the reform) of the 'shareholding company' (a limited liability shareholding company since the Chinese SOE reform) (Aivazian et al., 2005; Hassard et al., 2006). The shareholding company and the sponsor enterprise are affiliated because the sponsor enterprise continues to provide services and rent facilities to the shareholding company. Independent directors are those who do not have a material relationship with the focal shareholding firm or its affiliated firms. There are three types of independent director on a typical Chinese board: those connected to the state, those from financial institutions, and academics (Tian and Lau, 2001).

Arguably, a greater representation of independent directors on a board will provide a broader view regarding the company's strategic affairs. Compared with inside directors, they are more acute when it comes to seizing business opportunities and identifying potential problems. In addition to independent directors having professional knowledge and diverse experience, they are often capable of offering specialised advice on business issues and making better decisions. Also, from the resource dependence perspective, appointing independent directors who have abundant social network ties to strategically related organisations and thus access to valuable resources can bring such resources within the firm's 
boundaries, thus producing economic rents (Peng, 2004; Withers et al., 2012). This is more pronounced in China's cultural and institutional environment, which relies more heavily on social relationships than formal contracts to get things done (Peng, 2004). Based on the above discussion, we suggest the following hypothesis:

H1: Ceteris paribus, a greater representation of independent directors on the board positively influences the financial performance of new publicly listed firms in

\section{China.}

\section{CEO duality}

According to agency theory, the division of responsibilities of the top management in a firm should be clearly defined, such that no single person has unlimited decision-making authority. For instance, the UK government's CG guidelines recommend that the posts of CEO and chairman be separately held, in what is known as CEO non-duality ${ }^{6}$ (see Hussainey and AlNajjar, 2012; ICAEW, 2015). The CEO is responsible for formulating and implementing corporate strategies and managing the firm's functional activities, while the chairman directs the work of the board and monitors the performance of the CEO (Weir and Laing, 2001). As such, the chairman also has the power to oversee and control top managers' behaviours (Brickley, Coles and Jarrell, 1997). In so doing, an independent non-executive chairman is able to express objective opinions on strategic issues, monitor board decisions, and protect shareholders' interests.

Drawing on agency theory, it can be deduced that CEO duality may result in autocratic leadership and operational inefficiency in a firm, which are detrimental to its performance. The combination of the two posts is likely to result in unfettered decision-

\footnotetext{
${ }^{6}$ Among 34 OECD countries, only 14 governments require or recommend CEO non-duality (OECD, 2015). The CSRC has no regulations on the combination of the role of board chair and CEO of listed firms in China.
} 
making power being held by one individual, which destroys the promotion of operational efficiency and the achievement of outstanding financial outcomes. Thus, dual leadership status makes it difficult for directors to be objective and honest when evaluating organisational outcomes, which, in the long run, causes poor financial performance (Carver, 1990). It is necessary to appoint an independent non-executive chairman to restrict the decision-making discretion of top managers (Brickley et al., 1997). As such, separating decision management from decision control can largely reduce agency costs and promote the financial performance of publicly traded firms (Fama and Jensen, 1983).

However, proponents of CEO duality aver that combining the two roles saves on the additional compensation required to maintain two positions, and reduces conflicts between the CEO and directors, thus promoting the achievement of the firm's goals. Since the CEO is more familiar with management issues in the firm, an experienced CEO can deal efficiently with complex management challenges (Lam and Lee, 2008). Prior empirical research on the effect of CEO duality on firm performance is rather inconclusive (Krause et al., 2013), including findings of positive (Peng et al., 2007; Tian and Lau, 2001), negative (e.g. Daily and Dalton, 1994; Kiel and Nicholson, 2003), and no relation (e.g., Boyd, 1995; Wu et al., 1998), and of a mixed relationship (e.g., Baliga, Moyer, and Rao, 1996; Lam and Lee, 2008). These mixed results indicate that a universally optimal leadership structure may not exist. Thus, firms should choose the most suitable board leadership structure for their own business climate.

Compared with the era of the command economy, the new legal framework comprising laws such as the Bankruptcy Law and the State-owned Industrial Enterprises Law, introduced in the 1980s helped to improve the autonomy of Chinese firms in terms of split ownership and control (Lin and Germain, 2003; Tanner, 1999). Later, in the 1990s and 2000s, the Company Law governing limited liability companies and joint stock companies in 1993, 
many Chinese SOEs' business structures were improved and zombie firms were even expelled by the government (Berglöf and von Thadden, 2000; Hassard et al., 2006; McCann, 2014; OECD; 2011; Reuter, 2015). These legal and institutional frameworks for CG have also restructured Chinese firms' business towards the China-specific market economy. Thus, it is likely that the board leadership structure will be significantly improved in comparison to the period of institutional transition ( $c f$. Peng et al., 2007). Since these changes, an independent non-executive chairman is more likely to express an impartial voice on important corporate strategic issues and to scrutinise managerial behaviours. The separation of the posts of CEO and chairman enhances the monitoring capability and power of the board. This separated corporate leadership will eventually lead to a more effective CG structure and better financial performance in the period since China's institutional transition. Thus, we suggest the following hypothesis:

H2: Ceteris paribus, CEO duality negatively influences the financial performance of new publicly listed firms in China.

\section{Methods}

\section{Sample and data collection}

We collected data from 110 Chinese manufacturing firms that went public in 2010 on either the Shanghai or the Shenzhen Stock Exchange. The study sample is confined to publicly listed firms, due to the assumption that these firms apply the rules and standards set by regulatory bodies in carrying out their business activities (Ehikioya, 2009). In addition, listed firms are predicted to disclose their financial information in compliance with the authoritative accounting standards. We excluded highly diversified firms from the sample to minimise industry effects (Murthy, Rosenstein and Rangan, 1993; Tian and Lau, 2001).

The sample firms' business focuses include manufacturing sectors such as special 
equipment manufacturing, universal equipment manufacturing, computers, communications, and other electronic equipment manufacturing. They all operate within a similar regulatory environment, such that substantially different CG-performance relationships will not be present. Also, many Chinese SOEs in the manufacturing sector went through the SOE reforms (Motohashi and Yun, 2007; Wang et al., 2009). Thus the performance impacts of the SOE restructuring measures on board independence are likely to be more obvious. This setting provides an ideal research context for the investigation of the CG-performance relationship.

\section{Insert Table 1 here}

We collected the sample firms' performance data from their annual reports in 2012, two years after IPO. The year 2012 was chosen due to consideration of the time-lag issue. To be more specific, the CG structure and mechanism regarding board independence may not have an instant effect on financial performance. We judged that it would be better to observe the financial performance impact two years later. Prior studies on CG and performance also deal with the time-lag issue in this way (Barnhart et al., 1994; Bhagat and Black, 2000). Also, new IPO firms may manipulate financial information and conceal potential problems so as to gain a foothold in the market. Thus the financial data in 2010 and 2011 may be relatively inauthentic and unreliable for the 2010 IPO firms. In addition to the above sources, data were collected from Thomson DataStream, the China Statistical Yearbook, and the Stockstar to complement the data set. At the end, eight firms were deleted because of missing CG or financial information during the investigated period. The screening procedure left a total of 102 firms that are used in this research.

\section{Measurement}

Regarding the independent variables, board composition (INDEP) is measured by the 
proportion of independent directors, that is, the ratio of the number of independent directors to the total number of directors. CEO duality (DUAL) is a dichotomous variable with 1 standing for 'duality' and 0 for 'non-duality'.

As for the dependent variables, measures of firms' financial performance fit into two accounting-based measures, i.e., return on assets (ROA) and return on equity (ROE) (Tian and Lau, 2001). ROA is calculated as the ratio of net profit to total assets, indicating a firm's efficiency in generating earnings by making use of its assets. ROE is calculated as the ratio of net profit to shareholders' equity, revealing how well a firm utilises investment to achieve profits. Another reason that ROE is emphasised in Chinese research is that the CSRC has published regulations regarding ROE since 1996. It stipulates that 'a new public listed firm's ROE has to be at least 10 percent in each of the three most recent years and an already listed firm has to keep its ROE positive for three consecutive years to avoid being delisted' (Peng et al., 2007, p.214).

We control for variables that could affect firm performance. The first control variable is board size, which is measured as the total number of directors at the time of the IPO. If the board size is large, directors with specialised knowledge and diverse types of experience can work together to make superior decisions. Directors with more ties to the external environment can also bring in required resources, thus enhancing firm performance. However, a small board has its own benefits. Members of a small board are familiar with each other, and they are willing to participate frankly in discussions. Thus, it is much easier for a small board to reach consensus and achieve operational efficiency. The second variable is firm age, which is measured as the number of years that the firm has existed since incorporation. Firm age is included as a control variable for the reason that old firms in China may benefit from a stable supply of resources and rich industrial experience (Tian and Lau, 2001). We control for firm size, measured as the firm's total assets when it initially went 
public. Because of the heavy skewness in firm size, the log transformation of this variable is employed to ensure a normal distribution. Large firms have encountered more difficulties than small and medium-sized one when adjusting to a market-oriented economy (Tian and Lau, 2001). The last control variable is market munificence, which indicates the extent to which the industry environment supports organisational outcomes. Following the previous literature (Dess and Beard, 1984; Tian and Lau, 2001), market munificence is measured as the three-year average growth rate of industry-level sales revenue. Table 1 summarises the research measures.

\section{Insert Table 1 here}

\section{Results}

The descriptive statistics for the study variables are summarised in Table 2. The average proportion of independent directors on the board meets the one-third requirement prescribed by the CSRC (2003). However, since the CSRC does not clearly prescribe an optimal board leadership structure, Chinese public companies are free to choose whether or not they separate the positions of CEO and chairman. Around half of the sample firms (49 out of 102) combine the two roles while the rest (53) separate them, which is similar to the findings in Tenev, Zhang and Brefort's (2002) report on the leadership structure of Chinese publicly listed firms. The least independent board is composed of 33\% independent directors, while in the most independent board more than half of the directors are independent. On average, in the sample, the board includes $37 \%$ independent directors. The small standard deviation reveals that the data points are quite close to the mean, indicating that most boards contain around 37\% independent directors. This is in compliance with the CSRC guideline that stipulates that one-third of the board should be made up of independent directors. The smallest board contains five directors and the largest thirteen, which shows that all the sample 
firms follow the CSRC guideline on board size. The average board size is eight to nine directors, with a standard deviation of 1.59. Based on the log transformation of firm size, most firms are similar in size, close to the mean of 9.20. With regard to market munificence, the three-year average growth rate of industry-level sales revenue ranges from 0.09 to 0.19 , with a mean of 0.154 and a standard deviation of 0.036 . It is thus apparent that most firms have an industry-level sales revenue growth rate of $15 \%$. On average, firms generate earnings of $4 \%$ (ROA) and 3.64\% (ROE) by making use of corporate assets and shareholders' equity.

\section{Insert Table 2 here}

\section{Hypothesis test}

We conducted preliminary analyses to ensure there was no violation of the assumptions of normality, linearity, and multicollinearity in the sample. As the independent variables are not highly correlated $(r<0.7)$, as shown in Table 2 and all VIF values are less than 1.5 , there is no serious issue with multicollinearity in the sample. The presence of outliers is checked by inspecting the normal P-P plot. The data points lie in a roughly straight diagonal line from bottom left to top right, which assures us of a normal distribution. Most of the data points are concentrated in the centre around the origin and no standardised residual is beyond the range of -3.3 to 3.3 in the scatterplot; thus no outlier is present. The data are therefore appropriate for the regression analysis.

Next, we tested the hypotheses using multiple ordinary least squares regression analysis. The results are presented in Table 3. For each dependent variable, Models 1, and 3 include only the control variables, and Models 2 and 4 contain both the control variables and the independent variables.

We find that no control variable significantly affects $\mathrm{ROA}$, and the $\mathrm{R}^{2}$ value in Model 1 is very low $\left(\mathrm{R}^{2}=0.041\right)$. After entering the two independent variables (i.e., INDEP 
and DUAL) in the second step, the proportion of independent directors and CEO duality as a whole explain an additional $10 \%$ of the variance in ROA, even when the influences of board size, firm age, firm size, and market munificence are controlled for. There is no significant association between INDEP and ROA. Hence, $H 1$ is not supported. However, DUAL has a significantly negative effect on ROA $(b=-0.328, p<0.01)$, indicating that firms that separate the posts of CEO and chairman (i.e., CEO non-duality) have better accounting-based performance. Thus, $H 2$ is supported.

Models 3 and 4 in Table 3 present the regression results for ROE. The control variables are entered in the first step, and only explain $4.1 \%$ of the variance in ROE. After the two independent variables have been entered, the total variance explained by the whole model is $13.6 \%$. Thus, the two independent variables explain an additional $9.5 \%\left(\Delta \mathrm{R}^{2}=0.095\right)$, after controlling for board size, board age, firm size, and market munificence. As for the individual multiple regression coefficients, INDP insignificantly affects ROE $(b=0.031)$, but DUAL has a negative effect on $\operatorname{ROE}(b=-0.321, p<0.01)$. This result indicates that separating the posts of CEO and chairman would result in better accounting-based performance. Firm size has a negative effect on $\operatorname{ROE}(b=-0.234, p<0.05)$, but the other control variables have an insignificant relationship with ROE. Taking these results together, in this research only $H 2$ is supported, suggesting that 'CEO non-duality' has a strong positive effect on accountingbased financial performance. This finding is consistent with the agency theory.

Insert Table 3 here

\section{Post-hoc analysis}

Accounting-based measures such as ROA and ROE may be manipulated and distorted (Dalton et al., 1998). Market-based measures, on the other hand, represent the current market value placed on the firm, and are not distorted by accounting depreciation policies, asset 
valuations, historical financial information, and current operations (Kiel and Nicholson, 2003). Thus, market-based performance measures (e.g., stock return, Tobin's Q), which attach great importance to the firm's prospective profitability, could be used to complement accountingbased measures. Also, market-based measures take shareholder investment risks into consideration, thus reflecting risk-adjusted firm performance (Nayyar, 1992). Thus, following previous studies (Garg, 2007; Kiel and Nicholson, 2003; Tian and Lau, 2001), we test the relationship between CG and market performance. Tobin's Q can be calculated as the ratio of the firm's market value to the replacement cost of its assets. However, due to the unavailability of some of the variables used to calculate Tobin's Q, Chung and Pruitt's (1994) alternative formula is employed as an approximation to it. Namely, Tobin's Q is calculated as the sum of the market value of common stock, the book value of preferred stock, and the book value of long-term debt, divided by the book value of total assets.

Regarding the effect of the two independent variables (i.e., INDEP and DUAL) on market-based performance, neither of them significantly affects Tobin's Q. Although the hypotheses are not supported, the results are not entirely against our expectations. The proportion of independent directors has a positive effect on Tobin's Q $(b=0.065)$, while CEO duality has a negative effect $(b=-0.144)$. Taking these results together, we conclude that in this research 'CEO non-duality' has a positive effect on accounting-based financial performance.

\section{Discussions and Conclusion}

\section{CEO non-duality leads to better financial performance}

Our results show that CEO duality had a negative impact on the accounting-based performance (ROA and ROE) of listed Chinese manufacturing firms in 2010 (supporting H2). This negative association in China's post-institutional-transition era is contrary to Peng et 
al.'s (2007) study that found a positive relationship during the transition era from 1992 to1996. CEO non-duality allows the BOD to exercise its oversight function more effectively, which promotes financial performance (Vafeas and Theodorou, 1998). The CEO is responsible for managing daily business activities, while the BOD, situated at the apex of the internal control system, has the ultimate accountability for the functioning of the firm (Jensen, 1993). When the CEO holds both posts, one person controls the firm and holds unrestricted decision-making power. In such cases, the board is likely to become a 'rubber stamp' provider, dominated by the CEO (Abdullah, 2004). Thus, a board that is highly controlled by the top managers is incapable of overseeing the management effectively. This kind of structure will eventually lead to the destruction of shareholders' interests and organisational outcomes, thus incurring high agency costs (Ellstrand, Tihanyi and Johnson, 2002; Su, Xu and Phan, 2008). Conversely, an independent non-executive chairman can evaluate strategic proposals objectively and fairly. As an agent, the CEO is able to inspect and monitor managers' behaviours effectively. Thus, separating the roles of CEO and chairman puts the board in a powerful position, outside the influence of the managers. This will ultimately pay off in the form of a sound CG system and improved financial performance. Following institutional transitions such as the SOE reforms and regulatory changes to CG, a majority of the new Chinese firms that have gone public in the manufacturing sector are now moving towards developing more efficient CG systems.

The separation of ownership and control between CEO duality and non-duality structure can have a significant impact on firm performance (Baliga et al., 1996; Krause et al., 2013). Our finding advances research on corporate leadership structure by highlighting the significance of CEO non-duality in the Chinese post-institutional-transition era. However, within the complex nexus of CG-firm performance, CEO non-duality may not an all-round solution for designing and implementing an effective CG system, and institutions are in a 
state of flux in emerging economies (even in some of developed economies). Thus, the impact of other institutional factors (e.g., state ownership and political ties) on firm performance would be considered in the context of China (Kowalski et al., 2013; Krause et al., 2013; Zhu and Yoshikawa, 2016).

Regarding the results of the post-hoc analysis, impact of dual leadership status on market-based performance, the relationship is insignificantly negative. This is probably due to the underdeveloped capital markets in China. For instance, the turnover ratios of China's two stock exchanges are much higher than those of the US stock exchanges (see Economic Research, 2016; Liu, 2006; Xu and Wang, 1999). Chinese investors hold shares for only one or two months on average, while the mean holding period for shareholders in the US is eighteen months (Peng et al., 2007). Given the relative inefficiency of China's capital markets compared to those of advanced economies, it is unlikely that any positive effects of board leadership structure would be reflected in the sample firms' market-based financial performance measures such as Tobin's Q.

\section{Insignificant relationship between independent board composition and financial performance}

Our results indicate that independent board composition does not affect financial performance (H1 rejected). Compared with independent directors, inside and affiliated directors are not subject to the information asymmetry problem. Thus, inside and affiliated directors in China are better at making strategic decisions based on timely and reliable information (Tian and Lau, 2001). As inside and affiliated directors are well informed and familiar with the complexities of the firm's business, they are capable of responding quickly to potential market opportunities and operational problems. In addition, inside and affiliated directors can easily access human and financial resources within the firm (Bhagat and Black, 2000). Under 
these circumstances, they are less likely to collude with managers to pursue personal interests at the expense of shareholder interests. Unlike them, independent directors who own a small proportion of the firm's stocks may have limited incentives to oversee the management with sufficient care and passion (Adithipyangkul and Leung, 2015; Ma and Khanna, 2016).

To date, including shareholders' own representatives on the BOD has been restrained by the current government regulations of China (Bhagat and Black, 2000). There could be other reasons for the insignificant relationship between board independence and financial performance. First, independent directors are hired only on a part-time basis and are likely to be busy with their own business. Therefore, it is difficult for them to devote themselves to monitoring other firms, and they may lack the required expertise to understand professional business issues and have limited accessibility to timely and accurate internal information (Weir and Laing, 2001). As was mentioned earlier, compared with internal and affiliated directors, the reward and punishment mechanism for independent directors is not well developed in China (Ma and Khanna, 2016). Independent directors who own trivial amounts of their firm's stocks are not motivated to perform their oversight roles conscientiously. This may lead to further negligence of duties, which would be detrimental to firm performance. In fact, board independence has only been assigned high importance by Chinese firms in recent years. Its effects on firm performance are unlikely to materialise instantly. Also, many underlying problems appear because of the immature and underdeveloped independent director system. For example, as China lacks a comprehensive mechanism for assigning responsibilities and providing training to independent directors, some may be unskilled in overseeing and monitoring. Further, unlike firms in developed economies, most Chinese firms lack non-executive-director-led nomination committees for appointing independent directors (Tenev et al., 2002). In their absence, 'the nomination process of independent 
directors may not be truly independent and highly depends on the availability of gifted individuals' (Abdullah, 2004, p.52). As the appointed independent directors are not guaranteed to be independent and objective enough, there is a large possibility that they will not contribute in the same way that competent independent directors would. Thus, independent directors will only bring benefits to Chinese firms if they are embedded in a well-developed general Chinese board mechanism.

Another important reason for the rejection of $H 1$ could be due to the Chinese institutional context. The average percentage of independent directors on the boards studied meets the one-third requirement prescribed by the CSRC (2003). However, outside directors are not truly independent of the management as they have some material relationship with the firm (Abdullah, 2004; Tenev et al., 2002). For instance, some independent directors hold posts as paid consultants or some are hired by foundations sponsored by the firms themselves, and others have personal relationships with the managers, compromising their independent judgment (Bhagat and Black, 2000). Independent directors tend to be more generous in determining a CEO's remuneration if they were selected during that CEO's term of office (Holthausen and David, 1993). These outside directors, who have personal relationships with top managements, will not make objective judgments or take effective control of the board (Garg, 2007). Emerging economies such as China have not developed such a sound market mechanism yet (Hoskisson et al., 2000; Peng et al., 2007). Under an underdeveloped institutional environment of this sort, truly independent directors may not be appointed to boards (Huyghebaert and Wang, 2012).

Relational and social capital known as guanxi is critically important for the formation of business relationships in China (Peng, 2004; Tsui and Farh, 1997). Business activities are controlled more by public relations than by formal agreements (Tian and Lau, 
2001). It is assumed that a greater representation of inside and affiliated directors on its board will add value to a firm. In comparison with independent directors, inside and affiliated directors will be much more familiar with the top managers. The well-developed social interdependence will help them to communicate comfortably with each other. Thus, they are more likely to have a comprehensive understanding of business affairs and make superior strategic decisions. Also, appointing outside independent directors may be more applicable to individualistic and low-power-distance cultures such as the US and UK. China has a relatively collectivistic and high-power-distance culture, valuing interpersonal relationships and collective achievement (Berry et al., 2010; Hofstede, Hofstede and Minkov, 1997). As a result, a greater representation of independent outside directors on a board may not bring many benefits in the Chinese institutional context. However, we cautiously expect that if the strong and efficient market assumption held for China then the impact of board independence on financial performance might be positive as we expected, providing possible support for both agency and resource dependence hypotheses.

\section{Implications for managers and policy makers}

This research shows that board independence, as has been advocated by conventional wisdom, may not always improve financial performance. This finding is of great importance for MNCs operating in emerging economies such as in China. Any such corporation planning to apply the Anglo-American CG model to a subsidiary in China will probably need to be flexible in adapting its CG structure to fit the Chinese institutional environment. In such cases, a greater representation of independent directors on the board may not always provide much of a payoff. But, CEO duality is generally detrimental to financial performance in China. Through the establishment of a separated board leadership structure, the chairman can exert more effective control over the top management team and concentrate on primary duties such as 
strategic decision making. However, the design of the board leadership structure may be contingent on a firm's size or business scope and the challenges it faces (Kiel and Nicholson, 2003). For instance, for firms engaging in complex value-chain activities, separating the leadership structure would be a reasonable solution for the effective management of diverse resources and expertise spread across the firm's boundaries.

Our study provides implications for government policy makers. As developed economies published CG guidelines related to board independence in the 1990s, the Chinese government followed this trend, laying down regulations such as that concerning the minimum representation of independent directors on boards. However, CG requirements vary considerably with an individual firm's institutional environment (Krenn, 2016; Rahman, 2009). Thus, a specific public regulation prescribing ideal forms of board composition and leadership structures would be less applicable in economies where institutional settings are in a constant state of flux. Our results provide a nuanced implication that adopting a uniform board structure may not always result in superior firm performance in emerging economies (cf. Bozec and Bozec, 2012). In this vein, the proposed implementation of mandatory adjustments to CG standards may need to be cautiously evaluated prior to the execution of government policies (Huyghebaert and Wang, 2012).

This research demonstrates that CEO non-duality positively influences on accounting-based financial performance in the Chinese manufacturing sector while a greater representation of independent directors on the board does not. As such, agency theory is partially supported and separating the posts of CEO and chairman rather than combining them is more likely to pay off with improved financial performance. We conclude that no single CG theory could completely explain the relationship between board independence and firm performance, but they are complementary in specific circumstances. Thus, the choice of board structure for each firm will be endogenous and the benefits of a certain structure should 
be weighed against the potential costs. For instance, when the managerial ownership is high, managers' interests in a firm will be as great as those of the other shareholders. Under such circumstances, the need to include a large proportion of independent directors to oversee the managers could be much lower. Provided that the employment of independent directors has real and opportunity costs, it may be better for such a firm to recruit fewer independent directors to the board. Independent directors would be less important in such a firm than in one whose managers have mastered specialised skills and face no rivalry for their jobs. Overall, although a separated leadership structure promotes a firm's financial performance, a greater representation of independent directors on a board does not affect performance in China's post-institutional-transition era in the manufacturing sector. Thus, board independence, as has been advocated by conventional wisdom and government standards, may not always guarantee improved firm performance.

\section{Limitations and future research}

Some limitations exist in this research. First, in this study the sample is restricted to a cross section of 102 Chinese manufacturing firms that went public in 2010. When interpreting the empirical results of this study, the relatively small sample size limits the generalizability to other industry contexts. Also, although the time-lag issue is taken into consideration and performance data collected two years after transitioning to IPO (Barnhart et al., 1994; Bhagat and Black, 2000), the actual length of the time lag is unknown. Regarding the insignificant relationship between board composition and financial performance, we cannot exclude the possibility that such results might be due to the inaccurate estimation of the time lag. A longitudinal study with larger panel data would be needed to estimate whether the relationship identified by this research exists over time. In so doing, the changing patterns of board structures and their effects on firm performance could also be better identified. 
Second, other explanatory variables (e.g., the percentage of director ownership and the structure of board sub-committees) are not included in the model due to data unavailability. The impact of three different types of independent directors (e.g., state, financial institutions, and academics) on performance would be very interesting as they may be related to specific types of resources (e.g., political, industry experience, and academic knowledge). We recommend that future researchers include these variables in their models.

Third, additional control variables are needed to be included in the future research. For instance, CEO entrenchment (e.g., CEO age, tenure and compensation) could be used as control variables. Without controlling for these variables, we cannot entirely negate a possibility of an underestimation of the contribution of CEO duality to financial performance in the model (Core, Holthausen and Larcker, 1999). In addition, future researchers consider including measures of leverage, state ownership, and growth opportunities as control variables. In this study the sample is restricted to a cross section of Chinese manufacturing firms that went public in 2010. We suggest future studies expand the industry types and treat them as industry dummies to capture board-industry effects.

Although in this research we focus on the board and leadership structures as they are constituent parts of an effective internal CG system, other external CG mechanisms (e.g., market for corporate control, legal framework, and product market competition) should not be neglected in CG research (Liu, 2006; Walsh and Seward, 1990). Thus, it is suggested that future studies comprehensively include both internal and external CG mechanisms in the model to examine their explanatory power. Also, it would be potentially interesting to compare these relationships among indigenous local firms, international joint ventures, and wholly owned foreign subsidiaries in China.

When examining CG, there have been two contrasting views put forward about whether governments should intervene to regulate CG (see Vafeas and Theodorou, 1998). 
Proponents argue that uniformed governance structures mandated through guidelines make control more effective, so that top managers are monitored more effectively, which improves firm performance and protects shareholders' interests. However, it is costly for governments to impose uniform CG on firms due to differing governance demands and interests that depend on their specific regulatory and economic environments. Thus, the opposing view is that monitoring and control mechanisms should be left to the market. These contrasting views raise the question of whether a uniform governance mechanism is necessary to discipline management and improve firm performance. However, the current research cannot assess this issue as it investigates only the period after the government mandate in the Chinese context. We suggest future researchers compare the post-regulation period to pre-regulation, thereby identifying whether uniform governance structure driven by the government is more effective in monitoring and firm performance. Lastly, there is a trend of being dual-listed in emerging market MNCs. So comparing dual-listed versus non-listed Chinese firms would be an interesting future research avenue.

\section{References}

Abdullah, S.N. (2004). Board composition, CEO duality and performance among Malaysian listed companies, Corporate Governance, 4(4): 47-61.

Adithipyangkul, P. and Leung, T.Y. (2015). State ownership, legal institution, and independent director compensation: An exploratory study in China, The Chinese Economy, 48(6): 430-448.

Agrawal, A. and Knoeber, C.R. (1996). Firm Performance and mechanisms to control agency problems between managers and shareholders, Journal of Financial and Quantitative Analysis, 31(3): 377-397.

Bai, C., Liu, Q., Lu, J., Song, F., and Zhang, J. (2004). Corporate governance and market valuation in China, Journal of Comparative Economics, 32(4): 599-616.

Baliga, B.R., Moyer, R.C., and Rao, R.S. (1996). CEO duality and firm performance: What's the fuss?, Strategic Management Journal, 17(1): 41-53.

Barnhart, S.W, Marr, M.W., and Rosenstein, S. (1994). Firm performance and board composition: Some new evidence, Managerial and Decision Economics, 15(4): 329-340.

Barnhart, S.W. and Rosenstein, S. (1998). Board composition, managerial ownership, and firm performance: An empirical analysis, Financial Review, 33(4): 1-16. 
Baysinger, B. and Hoskisson, R.E. (1990). The composition of boards of directors and strategic control: Effects on corporate strategy, Academy of Management Review, 15(1): $72-87$.

Berglöf, E. and von Thadden, E.L. (2000). The changing corporate governance paradigm: implications for developing and transition economies, In Cohen, S.S. and Byod, G. (Eds.), Corporate Governance and Globalization, 275-306, Edward Elgar.

Berlin Initiative Group. (2000). German code of corporate governance. Berlin Initiative Group.

Berry, H., Guillén, M.F., and Zhou, N. (2010). An institutional approach to cross-national distance, Journal of International Business Studies, 41(9): 1460-1480.

Bhagat, S and Black, B. (2000). Board independence and long-term firm performance. Unpublished paper. University of Colorado.

Boyd, B.K. (1995). CEO duality and firm performance: A contingency model, Strategic Management Journal, 16(4): 302-312.

Bozec, R. and Bozec, Y. (2012). Use of governance indexes in the governance performance relationship literature: international evidence, Canadian Journal of Administrative Sciences / Revue Canadienne des Sciences de l'Administration, 29(1): 79-98.

Brickley, J.A., Coles, J.L., and Jarrell, G. (1997). Leadership structure: Separating the CEO and chairman of the board, Journal of corporate Finance, 3(3): 189-220.

Carver, J. (1990). Boards that make a difference: A new design for leadership in nonprofit and public organizations. San Francisco: Jossey-Bass.

Core, J.E., Holthausen, R.W., and Larcker, D.F. (1999). Corporate governance, chief executive officer compensation, and firm performance, Journal of Financial Economics, 51(3): 371-406.

Chung, K.H. and Pruitt, S.W. (1994). A simple approximation of Tobin's Q, Financial Management, 23(3): 70-74.

CSRC. (2003). China Securities Regulatory Commission. Available at: http://www.csrc.gov.cn/pub/csrc en/newsfacts (Accessed on 4 October 2015).

CSRC. (2011). China Securities Regulatory Commission. Available at: http://www.csrc.gov.cn/pub/csrc En/about/annual (Accessed on 31 October 2016).

Dahya, J. and McConnell, J.J. (2007). Board composition, corporate performance, and the Cadbury Committee recommendation, Journal of Financial and Quantitative Analysis, 42(3): 535-564.

Daily, C.M. and Dalton, D.R. (1994). Corporate governance and the bankrupt firm: An empirical assessment, Strategic Management Journal, 15(8): 643-654.

Dalton, D.R., Daily, C.M., Ellstrand, A.E., and Johnson, J.L. (1998). Meta-analytic review of board composition, leadership structure and financial performance, Strategic Management Journal, 19(3): 269-290.

Davis, J.H., Schoorman, F.D., and Donaldson, L. (1997). Toward a stewardship theory of management, Academy of Management Review, 22(1): 20-47.

Dess, G.G. and Beard, D.W. (1984). Dimensions of organizational task environment, Administrative Science Quarterly, 29(1): 52-73.

Economic Research (2016). Stock Market Turnover Ratio for China. Available at https://research.stlouisfed.org/fred2/series/DDEM01CNA156NWDB (Accessed: 1 
August 2016).

Ehikioya, B.I. (2009). Corporate governance structure and firm performance in developing economies: evidence from Nigeria, Corporate Governance, 9(3): 231-243.

Eisenhardt, K.M. (1989). Agency theory: An assessment and review, Academy of Management Review, 14(1): 57-74.

Ellstrand, A.E., Tihanyi, L., and Johnson, J.L. (2002). Board structure and international political risk, Academy of Management Journal, 45(4): 769-777.

Erkens, D.H., Hung, M., and Matos, P. (2012). Corporate governance in the 2007-2008 financial crisis: Evidence from financial institutions worldwide, Journal of Corporate Finance, 18(2): 389-411.

Fama, E.F. (1980). Agency problems and the theory of the firm, Journal of Political Economy, 88(2): 288-307.

Fama, E.F. and Jensen, M.C. (1983). Agency problems and residual claims, Journal of Law and Economics, 26(2): 327-349.

Filatotchev, F., Strange, R., Piesse, J., and Lien, Y-C. (2007). FDI by firms from newly industrialised economies in emerging markets: corporate governance, entry mode and location, Journal of International Business Studies, 38(4): 556-572.

Garg, A.K. (2007). Influence of board size and independence on firm performance: a study of Indian companies, Vikalpa, 32(3): 39-60.

Hassard, J., Morris, J., Sheehan, J., and Xiao, Y. (2006). Downsizing the Danwei: Chinese state-enterprise reform and the surplus labour question, International Journal of Human Resource Management, 17(8): 1441-1455.

Hermalin, B.E. and Weisbach, M.S. (1991). The effects of board composition and direct incentives on firm performance, Financial Management, 20(4): 101-112.

Hillman, A.J., Cannella, A.A., and Paetzold, R.L. (2000). The resource dependence role of corporate directors: Strategic adaptation of board composition in response to environmental change, Journal of Management Studies, 37(2): 235-255.

Hofstede, G., Hofstede, G.J., and Minkov, M. (1997). Cultures and Organizations. New York: McGraw Hill.

Holthausen, R.W. and David, F.L. (1993). Boards of directors, ownership structure, and CEO compensation. Working paper. University of Pennsylvania.

Hoskisson, R.E., Eden, L., Lau, C.M., and Wright, M. (2000). Strategy in emerging economies, Academy of Management Journal, 43(3): 249-267.

Hossain, M., Cahan, S.F., and Adams, M.B. (2000). The investment opportunity set and the voluntary use of outside directors: New Zealand evidence, Accounting and Business Research, 30(4): 263-273.

Hussainey, K. and Al-Najjar, B. (2012). Understanding the determinants of risk metrics/ISS ratings of the quality of UK companies' corporate governance practice, Canadian Journal of Administrative Sciences / Revue Canadienne des Sciences de l'Administration, 29(4): 366-377.

Huyghebaert, N. and Wang, L. (2012). Expropriation of minority investors in Chinese listed firms: The role of internal and external corporate governance mechanisms, Corporate Governance: An International Review, 20(3): 308-332. 
ICAEW. (2015). Codes and reports. Available at: http://www.icaew.com/en/library/subjectgateways/corporate-governance (Accessed: 3 March 2015).

Jackling, B. and Johl, S. (2009). Board structure and firm performance: Evidence from India's top companies, Corporate Governance: An International Review, 17(4): 492-509.

Jensen, M.C. (1993). The modern industrial revolution, exit, and the failure of internal control systems, The Journal of Finance, 48(3): 831-880.

Johnson, J., Daily, C., and Ellstrand, A. (1996). Boards of directors: A review and research agenda, Journal of Management, 22(3): 409-438.

Khanna, T. and Palepu, K.G. (2004). Globalization and convergence in corporate governance: evidence from Infosys and the Indian software industry, Journal of International Business Studies, 35(6): 484-507.

Kiel, G.C. and Nicholson, G.J. (2003). Board composition and corporate performance: how the Australian experience informs contrasting theories of corporate governance, Corporate Governance: An International Review, 11(3): 189-205.

Klapper, L.F. and Love, I. (2004). Corporate governance, investor protection, and performance in emerging markets, Journal of Corporate Finance, 10(5): 703-728.

Kowalski, P., Buge, M., Sztajerowska, M., and Egeland, M. (2013). State-owned enterprises: Trade effects and policy implications. OECD Trade Policy paper 147, OECD Publishing, Paris, France.

Krause, R., Semadeni, M., and Cannella, A.A. (2013). CEO duality: A review and research agenda, Journal of Management, 40(1): 256-286.

Krenn, M. (2016). Convergence and divergence in corporate governance: An integrative institutional theory perspective, Management Research Review, 39(11): 1447-1471..

Lam, T.Y and Lee, S.K. (2008). CEO duality and firm performance: evidence from Hong Kong, Corporate Governance, 8(3): 299-316.

Lefort, F. and Urzúa, F. (2008). Board independence, firm performance and ownership concentration: Evidence from Chile, Journal of Business Research, 61(6): 615-622.

Li, M.H, Cui, L, and Lu, J. (2014). Varieties in state capitalism: Outward FDI strategies of central and local state-owned enterprises from emerging economy countries, Journal of International Business Studies, 45(8): 980-1004.

Liang, N. and Li, J. (1999). Board structure and firm performance: New evidence from China's private firms, Academy of Management Annual Conference, 7-10.

Lin, X. and Germain, R. (2003). Organizational structure, context, customer orientation and performance: Lessons from Chinese state-owned enterprises, Strategic Management Journal, 24(11): 1131-1151.

Liu, Q. (2006). Corporate governance in China: Current practices, economic effects and institutional determinants, CESifo Economic Studies, 52(2): 415-453.

Luoma, P. and Goodstein, J. (1999). Research notes. Stakeholders and corporate boards: Institutional influences on board composition and structure, Academy of Management Journal, 42(5): 553-563.

Ma, J. and Khanna, T. (2016). Independent directors' dissent on boards: Evidence from listed companies in China, Strategic Management Journal, 37(8): 1547-1557.

McCann, L. (2014). International and comparative business, London: Sage. 
Meyer, K.E. (2004). Perspectives on multinational enterprises in emerging economies, Journal of International Business Studies, 35(4): 259-276.

Monks, R.A.G. and Minow, N. (2004). Corporate governance, Oxford: Blackwell.

Moore, C.B., Bell, R.G., Filatotchev, I., and Rasheed, A.A. (2012). Foreign IPO capital market choice: Understanding the institutional fit of corporate governance, Strategic Management Journal, 33(8): 914-937.

Motohashi, K. and Yun, X. (2007). China's innovation system reform and growing industry and science linkages, Research Policy, 36(8): 1251-1260.

Murthy, V., Rosenstein, S., and Rangan, N. (1993). Corporate governance structure and management effectiveness in banking: Evidence from acquiring firms. Working paper. Clemson University.

Nayyar, P.R. (1992). Performance effects of three foci in service firms, Academy of Management Journal, 35(5): 985-1009.

OECD. (1999). OECD Principles of corporate governance, Paris: OECD.

OECD. (2011). Corporate governance of listed companies in China: Self-assessment by the China Securities Regulatory Commission, OECD.

OECD. (2015). Corporate governance factbook, Paris: OECD.

Peng, M.W. (2004). Outside directors and firm performance during institutional transitions, Strategic Management Journal, 25(5): 453-471.

Peng, M.W., Zhang, S., and Li, X. (2007). CEO duality and firm performance during China's institutional transitions. Management and Organization Review, 3(2): 205-225.

Rahman, M. (2009). Corporate governance in the European Union: Firm nationality and the 'German' model, Multinational Business Review, 17(4): 77-98.

Reuter. (2015). China to make state firms stronger, restructure zombie firms. Available at: http://www.reuters.com/article (Accessed on 5 October 2015).

Rosenstein, S. and Wyatt, J.G. (1997). Inside directors, board effectiveness, and shareholder wealth, Journal of Financial Economics, 44(2): 229-250.

Scott, J. (1991). Networks of corporate power: A comparative assessment, Annual Review of Sociology, 17, 181-203.

Su, Y., Xu, D., and Phan, P.H. (2008). Principal-principal conflict in the governance of the Chinese public corporation, Management and Organization Review, 4(1): 17-38.

Tanner, M.S. (1999). The politics of lawmaking in post-Mao China: Institutions, processes, and democratic prospects. OUP Catalogue.

Tenev, S., Zhang, C., and Brefort, L. (2002). Corporate governance and enterprise reform in China, Washington D.C.: World Bank and the International Finance Corporation.

Tian, J.J. and Lau, C.M. (2001). Board composition, leadership structure and performance in Chinese shareholding companies, Asia Pacific Journal of Management, 18(2): 245-263.

Tsui, A.S. and Farh, J.L. (1997). Where Gunaxi matters: Relational demography and Gunaxi in the Chinese context, Work and Occupations, 24(1): 56-79.

UNCTAD. (2015. World Investment Report 2014. Available at: http://unctad.org (Accessed: 2 March 2015).

Vafeas, N. and Theodorou, E. (1998). The relationship between board structure and firm performance in the UK, The British Accounting Review, 30(4): 383-407. 
Walker, G. and Madsem. T.L. (2014). Modern competitive strategy, New York: McGraw-Hill.

Walsh, J.P. and Seward, J.K. (1990). On the efficiency of internal and external corporate control mechanisms, Academy of Management Review, 15(3): 421-458.

Wang, J., Zhao, J. Ning, Y., and Yu, P. (2009). Transformation of Chinese state-owned enterprises: Challenges and responses, Multinational Business Review, 17(4): 99-122.

Weir, C. and Laing, D. (2001). Governance structures, director independence and corporate performance in the UK, European Business Review, 13(2): 86-95.

Whitley, R. (2007). Business systems and organizational capabilities: The institutional structuring of competitive competences. OUP Catalogue.

Williamson, O.E. (1984). Corporate Governance, Yale Law Journal, 93, 1197-1230.

Withers, M.C., Hillman, A.J., and Cannella, A.A. (2012). A multidisciplinary review of the director selection literature, Journal of Management, 38(1): 243-277.

Wright, M., Filatotchev, I., Hoskisson, R.E., and Peng, M.W. (2005). Strategy research in emerging economies: Challenging the conventional wisdom, Journal of Management Studies, 42(1): 1-33.

Wu, S.K., Bo, J., and Xi, Y.M. (1998). CEO duality: Empirical studies on Chinese listed companies, Economic Research Journal, 8, 21-28.

Xie, B., Davidson, W.N., and DaDalt, P.J. (2003). Earnings management and corporate governance: the role of the board and the audit committee, Journal of Corporate Finance, 9(3): 295-316.

$\mathrm{Xu}, \mathrm{X}$. and Wang, Y. (1999). Ownership structure and corporate governance in Chinese stock companies, China Economic Review, 10(1): 75-98.

Zhu, H. and Yoshikawa, T. (2016). Contingent value of director identification: The role of government directors in monitoring and resource provision in an emerging economy, Strategic Management Journal, 37(8): 1787-1807. 


\section{Figures and Tables}

\section{Figure 1. Conceptual model}

Institutional changes in code of corporate governance for listed firms in China
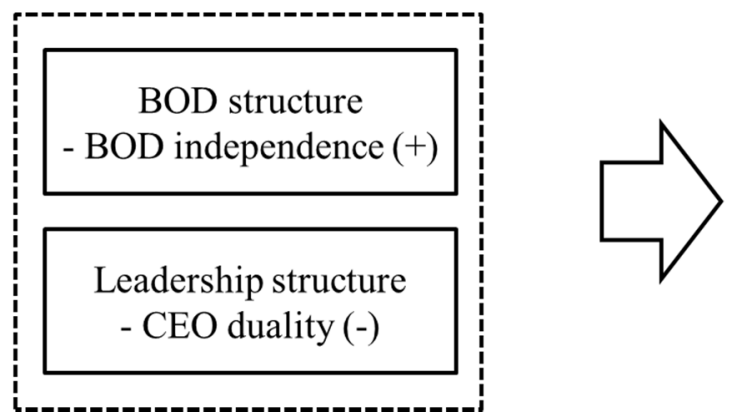

Financial performance

\section{Table 1. Measurement}

\begin{tabular}{ll}
\hline Variable & Measurement \\
\hline $\begin{array}{l}\text { Proportion of independent directors } \\
\text { (INDEP) }\end{array}$ & Number of independent directors/ Total number of directors \\
CEO duality (DUAL) & 1 for duality, 0 for non-duality \\
Board size (BSIZE) & Total number of directors at the time of IPO \\
Firm age (FAGE) & Number of years the firms has been existed \\
Firm size (FSIZE) & Firm's total assets at the time of IPO \\
Market Munificence (MUNI) & $\begin{array}{l}\text { Three-year average growth rate of industry-level sales } \\
\text { revenue }\end{array}$ \\
ROA & Net profits / Total assets \\
ROE & Net profits / Shareholders' equity \\
Tobin's Q & (MV of common stock + BV of preferred stock + BV of \\
\hline
\end{tabular}

Note: MV: market value; BV: book value. 
Pre-print (non-publisher's document)

Table 2. Descriptive statistics for study variables

\begin{tabular}{|c|c|c|c|c|c|c|c|c|c|c|c|}
\hline \multirow{2}{*}{ Variable } & \multirow{2}{*}{ Mean } & \multirow{2}{*}{$\mathrm{SD}$} & \multicolumn{9}{|c|}{ Correlation } \\
\hline & & & 1 & 2 & 3 & 4 & 5 & 6 & 7 & 8 & 9 \\
\hline 1. INDEP & 0.365 & 0.057 & - & & & & & & & & \\
\hline 2. DUAL & 0.480 & 0.502 & 0.153 & - & & & & & & & \\
\hline 3. BSIZE & 8.540 & 1.487 & $-0.558 * *$ & $-0.205^{*}$ & - & & & & & & \\
\hline 4. FAGE & 12.520 & 4.012 & 0.077 & 0.022 & -0.106 & - & & & & & \\
\hline 5. FSIZE $(\lg )$ & 9.200 & 0.357 & -0.007 & $-0.214^{*}$ & $0.198 *$ & -0.160 & - & & & & \\
\hline 6. MUNIF & 0.154 & 0.036 & 0.036 & 0.096 & -0.120 & 0.136 & $-0.205^{*}$ & - & & & \\
\hline 7. ROA & 0.040 & 0.062 & -0.067 & $-0.291 * *$ & 0.063 & 0.079 & -0.106 & 0.150 & - & & \\
\hline 8. ROE & 0.036 & 0.179 & -0.021 & $-0.267 * *$ & 0.011 & 0.111 & -0.177 & 0.039 & $0.830 * *$ & - & \\
\hline 9. Tobin's Q & 2.019 & 1.423 & 0.037 & -0.088 & -0.037 & -0.043 & -0.118 & $0.291 * *$ & 0.511 & $0.311 * *$ & - \\
\hline
\end{tabular}

$\mathrm{N}=102, \quad * p<0.05$ (two-tailed), $\quad * * p<0.01$ (two-tailed) 
Table 3. Results of regression analysis

\begin{tabular}{lcccc}
\hline & \multicolumn{2}{c}{ ROA } & \multicolumn{2}{c}{ ROE } \\
\cline { 2 - 5 } & Model 1 & Model 2 & Model 3 & Model 4 \\
\hline Constant & - & - & - & - \\
BSIZE & 0.103 & 0.049 & 0.055 & 0.019 \\
FAGE & 0.700 & 0.047 & 0.089 & 0.078 \\
FSIZE & -0.090 & -0.148 & $-0.174^{*}$ & $-0.234^{*}$ \\
MUNIF & 0.136 & 0.151 & -0.002 & 0.013 \\
INDEP & & 0.000 & & 0.031 \\
DUAL & & $-0.328^{* *}$ & & $-0.321^{* *}$ \\
\hline$F$ & 2.591 & 1.041 & 2.492 \\
$R^{2}$ & 1.037 & 0.141 & 0.041 & 0.136 \\
Adjusted $R^{2}$ & 0.041 & 0.086 & 0.002 & 0.081 \\
\hline
\end{tabular}

$\mathrm{N}=102, \quad * p<0.05$ (two-tailed), $\quad * * p<0.01$ (two-tailed) 